\title{
Cell Therapy in Type 1 Diabetes
}

\section{Maria Concetta Gioviale ${ }^{1}$, Maurizio Bellavia ${ }^{1}$, Giuseppe Damiano ${ }^{1}$ and Giuseppe Buscemi ${ }^{1,2,3}$ \\ ${ }^{1}$ Department of Surgical and Oncological Disciplines, Transplant Unit, University Hospital, School of Medicine -University of Palermo, Italy ${ }^{2} \mathrm{PhD}$ Research in Surgical Biotechnology and Regenerative Medicine}

${ }^{3}$ Consorzio InterUniveritario dei Trapianti d'Organo, Rome, Italy

\begin{abstract}
The incidence of diabetes mellitus has grown exponentially in the last few years. Etiopathogenesis of diabetes implies a $\beta$-cells damage in the islet of Langerhans, either through an autoimmune reaction present in type 1 diabetic patients or through altered function within these cells that affect their ability to secrete a properly functioning insulin hormone, in patients suffering from type 2 diabetes.

Exogenous insulin supply is, at the moment, the therapy of choice of the disease but it does not allow tight contro of glucose regulation, leading to long-term complications. Over the past few decades, pancreas or pancreas-kidney organ transplantation has been the most effective treatment for severe diabetic patients. Recently, an alternative promising therapeutic approach, consisting of successful pancreatic islet transplantation to reconstitute the insulin producing $\beta$ cells, has also emerged. Unfortunately the number of donor islets is too low compared to high number of patients needing a transplant, so the search for new renewable sources of high-quality $\beta$-cells becomes highly topical.
\end{abstract}

In this review, starting from the description of state of art of islet transplantation, we summarize the more recent promising approaches to the generation of new $\beta$-cells giving a big enfacy to adult stem/progenitor cells.

Keywords: Type I diabetes cell therapy; Pancreatic progenitor cells; Islet transplantation; Transdifferentiation of exocrine pancreatic cells.

Abbreviations: ADSCs (adipose derived stem cells): BM (bone marrow): EPCs (endothelial progenitor cells): ESRD (end stage renal disease): ESCs (embryonic stem cells): IAK (islet transplantation after kidney grafting): HGF (hepatocyte growth factor): hPDMSCs (human placenta derived mesenchymal stem cells): HSCs (hematopoietic stem cells): IPCCs (insulin producing cell clusters): IPSs (induced pluripotent stem cells): MSCs (mesenchymal stem cells): STZ (streptozotocin).

\section{Introduction}

The goal of therapy of type 1 diabetes (DM-1) is to restore a glycometabolic picture as close as possible to normal.

Since the cause of type I diabetes is the failure to produce insulin due to the destruction of $\beta$-pancreatic cells, the therapy is represented by the replacement of lost endocrine function. Since 1921, when Nicolae Constantin Paulescu, first in the world, was able to cure diabetes, having discovered insulin which he called Pancreina, for most patients the replacement therapy is the exogenous insulin supply. It has long been searching for therapeutic solutions able to 'cure' diabetes permanently, that is to replace the $\beta$-pancreatic cells, freeing patients from daily insulin requirements.

The more radical solution is the whole pancreas transplant, a surgical procedure developed in the last ten years, which has reached success rates comparable to those of other organ transplants $(80 \%$ of transplanted patients achieved insulin independence and maintained for more than 6-8 years) [1].

However, pancreas transplantation is a challenging surgical procedure, requires a significant immunosuppressive therapy to prevent organ rejection and, therefore, takes place only in combination with a kidney transplant in diabetic patients with ESRD (end stage renal disease) on dialysis [2].

In the last few years islet transplantation has been developed as an alternative promising therapy but, more recently, experimental approach consisting of stem cells administration, transdifferentiation of ductal cells or genetic reprogramming seem the future of diabetes cell therapy

\section{Pancreatic Islet Transplant}

\section{General considerations}

The islets of Langerhans are clusters of endocrine cells and constitute about $1 \%$ of pancreatic tissue where they play a function of sensing glucose blood levels, secreting hormones that regulate them.

The pancreatic islets for transplantation are prepared by an isolation procedure, developed by Camillo Ricordi, which consists of a combined mechanical and enzymatic digestion of the pancreas, followed by a purification step through gradients of different density (Ricordi Chamber) (Table 1).

The possibility to culture pancreatic islets offers a range of therapeutic opportunities aimed at improving the efficiency and graft survival, which also is made with a technique much simpler than that required for vascularised pancreas transplantation. This procedure is associated with low morbidity and can be repeated, to give an additional dose of islets, when it is necessary to achieve adequate metabolic control and insulin independence.

*Corresponding author: Maria Concetta Gioviale, PhD, Transplant Unit University Hospital, University of Palermo, Dep't of Surgical and Oncological Disciplines, Via del Vespro 129, 90127 Palermo Italy, Tel: +390916552666; Fax: +390916552634; E-mail: attilioignazio.lomonte@unipa.it

Received October 14, 2011; Accepted November 21, 2011; Published December 03, 2011

Citation: Gioviale MC, Bellavia M, Damiano G, Buscemi G (2011) Cell Therapy in Type 1 Diabetes. J Stem Cell Res Ther S2:004. doi:10.4172/2157-7633.S2-004

Copyright: @ 2011 Gioviale MC, et al. This is an open-access article distributed under the terms of the Creative Commons Attribution License, which permits unrestricted use, distribution, and reproduction in any medium, provided the original author and source are credited. 
The first islet transplants performed in patients with type 1 diabetes mellitus (DM-1) and under immunosuppressive therapy for organ transplantation, have been characterized by a low success rate, expressed in terms both of insulin independence and recovery of c-peptide secretion, due to the inconsistent quality of the transplanted islets and inadequate immunosuppression [3]. The revival of this procedure occurred with the development of an innovative scheme of immunosuppression, known as the 'Edmonton Protocol', and its application in selected centers in the world able to reproducibly obtain high quality islets $[4,5]$. The first results were excellent, with a success rate at one year of almost $100 \%$, although, with continued experience, these decreased dramatically, especially at 2-3 years, but these data were of extraordinary importance because they helped to stimulate research in the field of $\beta$-cell replacement.

\section{Benefits of islet transplantation}

The goal of islet transplantation is to control blood sugar levels, restoring $\beta$-cell function. The tight control of blood glucose, obtained by administering intensive insulin therapy, has shown great benefits in preventing or delaying the progression of micro and macro-vascular chronic complications of diabetes, but these benefits are associated with an increased risk of acute severe hypoglycaemia [6,7].

The islet transplantation could be considered a valuable therapeutic option to achieve a short-term metabolic control in patients with DM-1 with frequent and severe episodes of hypoglycemia without prodromal symptoms.

Immediately after the infusion of islets, also in cases of sub-optimal cell mass, it happens a dramatic reduction in daily insulin requirement, which is associated to an improvement in glycemic control, demonstrated by normalization of glycated hemoglobin, improvement in the c-peptide levels and insulin secretion during metabolic tests [8].

Although clinical trials, made in the 80s and 90s, have shown that graft function (defined clinically as the persistence of measurable levels of c-peptide in the blood) can be sustained over time, the insulinindependence was achieved for a limited period in a fraction of patients.

\section{Tab 1: Procedure for isolation of pancreatic islets}

Pancreatic islet cells are obtained from multiorgan donors after separation from the tissue surrounding the gland

I) The Wirsung duct is cannulated to allow injection of a solution containing collagenase in order to relax the organ and enable the achievement of an effective enzyme activity during the dissociation

॥ The gland is then divided into several parts and transferred to the dissociation chamber, consisting of a lower portion, where the pancreas is inserted together with metal balls, and an upper portion consisting of an inverted funnel, separated by a porous metal filter with a specific porosity

I) The digestion process is the combination of the enzymatic effect (obtained by increasing the temperature) and mechanical (generated by the action of the ball during the stirring of the room) that results in the release of fragments of the pancreas that can pass through the filter metal due to the unidirectional flow of liquid dissociation

॥ The digested pancreas is, then, purified by using different density gradients (continuous and discontinuous) in order to enrich the endocrine component

I) The islets that make up only $1 \%$ of pancreatic tissue can be viewed using a dye that gives it a distinctive red color

॥ After the purification enriched fractions containing levels of purity can be obtained
Recent clinical studies have shown that insulin independence can be achieved after repeated infusions of islets, using immunosuppressive protocols without steroids $[9,10]$.

The normalization of glycated hemoglobin and insulinindependence are generally obtained after transplantation of a sufficient number of islets ( $>13,000$ islet equivalents / $\mathrm{kg}$ recipient body weight) in a single infusion or repeated infusions $[11,12]$.

Other studies have reported insulin independence in $80 \%$ of patients at one year, when a protocol of sequential islet transplantation, in order to reach a sufficient mass, was performed [13].

Data suggest that transplantation provides a better metabolic and physiological control compared to insulin treatment; in particular islet transplantation allows a long-term prevention of severe hypoglycemia also when an insulin supportive therapy is required to maintain stable blood sugar levels (in the case of insufficient mass of transplanted islets or partial engraftment of them) $[14,15]$.

The effects of islet transplantation on the progression of diabetes complications are currently under investigation, but it has been shown an improvement of left ventricular ability and no increase in carotid wall thickness during a three years follow-up post-transplant. An improvement in renal function after IAK (islet transplantation after kidney grafting), was also observed in patients with chronic renal failure and DM-1. Another interesting observation is the increase of blood flow in central retinal artery and vein [16].

\section{Limits of islets transplantation}

There are still many obstacles to overcome before achieving a successful islet transplantation in humans. There are several factors to consider to optimize pancreatic islets transplantation:

- Cold storage of pancreas before islet isolation should be less than eight hours;

- The quantity of islet cells: it should be transplanted a minimum of $6000 \mathrm{IE} / \mathrm{kg}$ per weight of the recipient (where IE indicates islet equivalents: an expression of the volume of islets, converted to the number of islets with a diameter of 150 micrometers).

- Administration of antilymphocyte antibodies at the time of islet transplantation

- Site of the transplant: currently liver is preferred;

- Adverse effects of immunosuppressive therapy based on the use of corticosteroids;

- Recurrence of the autoimmune processes associated with the DM-1;

- Ischemic processes that may affect the islet cells themselves.

\section{Transplant of encapsulated islets}

A variation to islet transplant, which is under experimentation, consists of their encapsulation with a selective, natural and nonimmunogenic membrane that allows free transport of oxygen, nutrients and hormones, but particularly a tolerance of humoral and cellular immune system against these "masked" islets. This would eliminate or reduce the need of immunosuppressive therapy $[17,18]$.

This membrane is a polysaccharide, sodium alginate, which, in contact with islet cells in a solution of calcium chloride, manages 
to wrap. The following islets transplantation is performed in the peritoneum $[19,20]$.

\section{Islets/stem cells combined transplant}

Experimental data indicate that bone marrow transplant leads to a state of chimerism (coexistence of immune cells of the donor with those of the recipient) which can re-educate the recipient's immune system to accept transplanted organs or tissues from the same donor without the need of immunosuppressive therapy. Stem cells could reconstitute the immune system of the donor into the recipient, "teaching" the recipient to accept the islet from the same donor [21]. These experiments have already proved effective in experimental animal models, but not in clinical trials.

\section{Stem Cells: A Source for new $\beta$-Cells}

\section{Pancreatic stem cells}

The postnatal pancreatic duct may harbour islet precursor/ stem cells because of specific cellular migrations during embryonic development [22]. Islet neogenesis, the generation of new islets from pancreatic stem/progenitor cells located in ducts, could be an active process in the postnatal pancreas; interestingly insulin-producing cells can be generated from adult pancreatic ductal tissues in vitro [23-28]. Fluorescent activated cell sorting, which allows characterization of human $\beta$-cells through CD95 [29], could be also a promising technique for isolation of multipotent pancreatic progenitors from both neonatal and adult pancreata. By combining flow cytometry and clonal analysis $[30,31]$, some authors described molecular markers expressed specifically by possible pancreatic stem/progenitor cells candidate as the hepatocyte growth factor (HGF) c-Met. Moreover, they identified a newly specific marker for ductal cells, CD133 [31].

The use of adult stem cells isolated from patients could solve immunological problems associated to cell transplant. Unfortunately, adult stem cells are rare and difficult to expand in culture. In contrast, it has been reported that new generation of $\beta$-cells, after birth, could take origin from existing cells, and not from putative pancreatic stem cells [30]. Insulin-producing $\beta$ cells are also produced from endogenous endocrine progenitors following injury [31]. The existence of adult pancreatic stem/progenitor cells and their ability to proliferate in response to particular stimuli should be more investigated.

\section{Stem cells of no pancreatic origin}

Recent studies have demonstrated that embryonic stem cells (ESCs) [32-34], induced pluripotent stem cells (IPSs) [35,36], and adult stem cells form bone marrow (BM) [37] pancreas [38,39], liver [40], umbilical cord blood [41], Wharton's jelly [42], placenta [43], could differentiate into insulin producing cells. Because of their high pluripotency ESCs could be ideal for islet regeneration, but obviously their use is under debate for ethical/legal issues and risks of teratoma formation [44].

The seminal work regarding the potentiality of ESCs to differentiate to insulin secreting structure similar to pancreatic islets was published by Lumelsky and co-workers [32]. In this work authors identified a highly enriched population of nestin-positive cells from embryoid bodies (EBs) as possible candidates for pancreatic islets generation. EBs were plated into a serum-free medium to achieve a negative selection for all cell types different from nestin-positive cells. These cells were then expanded in the presence of a mitogen, basic fibroblast growth factor (bFGF), in N2 serum-free medium, followed by mitogen withdrawal to promote cessation of cell division and differentiation.

Using a RT-PCR (reverse transcription polymerase chain reaction) authors showed that the ES cells processed following their protocol expressed GATA-4, a marker of definitive and visceral endoderm, HNF3b, a marker of definitive endoderm, as well as markers of pancreatic cell fate, including the murine insulin I, insulin II, islet amyloid polypeptide (IAPP), and the glucose transporter- 2 (GLUT 2). Glucagon, a marker for the pancreatic a cells, was also induced in differentiated cells. The acquisition of a pancreatic fate was also confirmed by immunocytochemical analysis which showed insulin staining after mitogen withdrawal, resulting in many strongly insulin positive cells by the end of the processing.

The ability of ES cell-derived islet-like cell clusters to survive and function in vivo was tested through grafting cell clusters subcutaneously in the shoulder of streptozotocin-diabetic mice. Implanted cells vascularized, remained immunoreactive to insulin and formed aggregates morphologically similar to normal pancreatic islets. Authors did not observe a sustained correction of hyperglycemia, although grafted animals were able to maintain their body weight and survived for longer periods of time than hyperglycemic sham-grafted controls.

Boyd and colleagues [45] published a work which raised doubts about the Lumelsky's protocol. The first was about the interpretation of gene expression data regarding the pancreatic markers; Boyd et al infact assert that it should be defined whether the gene expression was attributable to a single cell within the isolated cluster or whether all cells in the cluster had transcribed the genes. Furthermore, Lumelsky's data showed that "insulin producing cell clusters" (IPCCs) had a mixed pancreatic phenotype because they express not only $\beta$-cells markers but also those of $\alpha$-cells.

Another weakness in Lumelsky's protocol emerged from quantitative PCR data [45], which demonstrated that expression of insulin-1 and insulin-2 mRNA was consistently higher in IPCCs obtained by Blyszczuk and coworkers [46] compared to Lumelskygenerated clusters, implying that the Blyszczuk protocol was capable of generating IPCCs with superior de novo insulin-producing activity. The amylase-2 expression in IPCCs obtained by other groups following Lumelsky's protocol [47] suggested that the protocols may promote also exocrine differentiation; this evidence was not in favor of a unique $\beta$-cell phenotype acquired by ESCs. Rajagopal et al, observed also, though immunofluorescence, an attenuated relative ratio of c-peptide to insulin suggesting that the insulin content of IPCCs is an unequal combination of de novo synthesis and adsorption from the culture medium [48] Most notably, however, the Blyszczuk protocol [46] consistently produced the highest level of c-peptide indicating that this protocol was capable of superior de novo synthesis of insulin. Furthermore cell clusters obtained from Lumelsky and Blyszczuk showed prominent glucagon containing [45] with insulin indicating, that IPCCs derived from ESCs may not surrogate $\beta$ cells but may, in contrast, more closely resemble a hybrid of $\alpha$ and $\beta$ cells. Boyd et al. proposed that glucagon/ insulin costaining could alternatively indicate that IPCCs derived from ESCs were developmentally immature endocrine cells as suggested by an high expression of neurogenin-3 which, instead, is downregulated in fully mature islets [49]. Authors suggested also that IPCCs could be defective in their glucose-sensing capacity in vivo. This contention was supported by the glucose stimulation assays that showed that 
IPCCs released insulin in response to minimal glucose stimulation (3.3 $\mathrm{mmol} / \mathrm{l}$ glucose) but did not release significant amounts of insulin at higher glucose stimulation ( $25 \mathrm{mmol} / \mathrm{l}$ glucose).

In light of the aforementioned issues it seems that ESCs based strategy to obtain pancreatic islet like cells needs further investigations.

A valid alternative to ESCs could be adipose derived stem cells (ADSCs) because of their abundance, availability and possibility to be used for autologous transplant [50]. In this regard at least three different research groups showed that ADSCs could, under specific culture conditions, differentiate into insulin, somatostatin, and glucagon expressing cells or c-peptide positive cells [51,52]. In particular Chandra and coworkers [53] packed these cells in immunoisolation capsules and tested their in vivo/in vitro functionality demonstrating their ability to restore normoglycemic conditions in streptozotocin-induced diabetic mouse. Interestingly this study showed, for the first time, that also undifferentiated ADSCs were able to determine a moderate control of blood glucose levels, leading to the speculation that the autocrine and paracrine factors of regenerating pancreas and hyperglycemic local diabetic micro-environment of mice may contribute to ADSCs differentiation. It is worthy of noting that such a phenomenon it has also been shown for bone marrow derived stem cells [54].

Islet neogenesis from the constitutively nestin expressing human umbilical cord matrix derived mesenchymal stem cells has also been reported. Kadam and co-workers [55] showed that human placenta derived mesenchymal stem cells (hPDMSCs) could differentiate in islet-like cells able to restore normoglycemia when transplanted under the kidney capsules of streptozotocin-induced diabetic mice. Interestingly a gene expression profile of undifferentiated hPDMSCs showed, unlike human cord blood or amnion derived mesenchymal stem cells, that they express mRNA for insulin, glucagon, somatostatin, Ngn3, and Isl1.

\section{Stem cells as a support for islet function and regeneration}

Vascularisation of pancreatic islets is important for their ability to secrete insulin. Obviously islet isolation [56] needs a break of vascularisation which could compromise irremediably endocrine function; some preservation methods counteract this deleterious effect $[57,58]$.

Endothelial cells deliver oxygen and nutrients to endocrine cells, and contribute to create a microenvironment for beta-cells function. In particular, they can induce insulin gene expression during islet development, stimulate beta-cell proliferation, and produce a number of vasoactive, angiogenic substances and growth factors [59-61].

Published works reported the ability of hematopoietic stem cells (HSCs), mesenchymal stem cells (MSCs), and endothelial progenitor cells (EPCs) to contribute to islet revascularization through vessel formation by differentiation into mature endothelial cells (EPCs) or release of proangiogenic factors such as hepatocyte growth factor (HGF) and vascular endothelial growth factors A [62-64]. In this regard Mathew et al [65] provided evidence that bone marrow derived EPCs, transplanted after a pancreatic injury, migrate to the site of damage helping the recovery of injured beta-cells even if they do not differentiate in insulin-producing cells.

Two other papers stress the concept of a synergism between $\beta$-cells and bone marrow (BM) derived cells. Sakata et al [66] showed that only a combined transplant (under the kidney capsule) using total bone marrow derived cells (not only mesenchymal cellular fraction) and islets was able to significantly lower blood glucose levels in a streptozotocin-induced diabetes murine model; interestingly in the case of transplant of BM cells alone there were no normoglycemic mice and no insulin-positive cells, suggesting that a direct differentiation of BM cells in beta-cells was unlikely. Ito and colleagues [67] provided similar evidence but in this case the site of combined BM cells/islets transplantation was liver and not kidney.

BM derived stem cells could also have a role in stimulation of $\beta$-cells regeneration [68-70]. For example, it has been shown that infusion of mesenchymal stem cells in NOD/SCID mice, after STZinduced islet destruction, could increase the number of endogenous $\beta$-cells improving hyperglycemia.

\section{Beyond Stem Cells based Therapy: Transdifferentiation of Adult Cells towards an Islet like Phenotype}

The pancreas development starts with dorsal and ventral protrusions of the primitive gut epithelium that fusing later to form the definitive organ characterized by the appearance of glucagonproducing cells (Figure 1). Then a few insulin-producing cells appear, often co-expressing the glucagon hormone. A later step consists of a peak of endocrine cell genesis leading to the generation of numerous fully differentiated insulin-expressing $\beta$-cells and glucagon-producing $\alpha$-cells. At the end of pancreas development endocrine cells begin to form well-organized islets of Langerhans.

The mechanisms responsible for the development of these different endocrine cell types are not fully understood, but experiments consisting of generation of mice deficient for a number of pancreatic transcription factors helped to shed more light about them identifying Sox9, Pdx1, Ngn3, IA1, Pax4, Arx, Nkx2.2, Nkx6.1, Nkx6.2, Pax6, and MafA as crucial mediators of organ development [71].

All pancreatic cells derive from Pdx1-expressing progenitor cells [72] and this recent information was at the basis of a lot of experiments

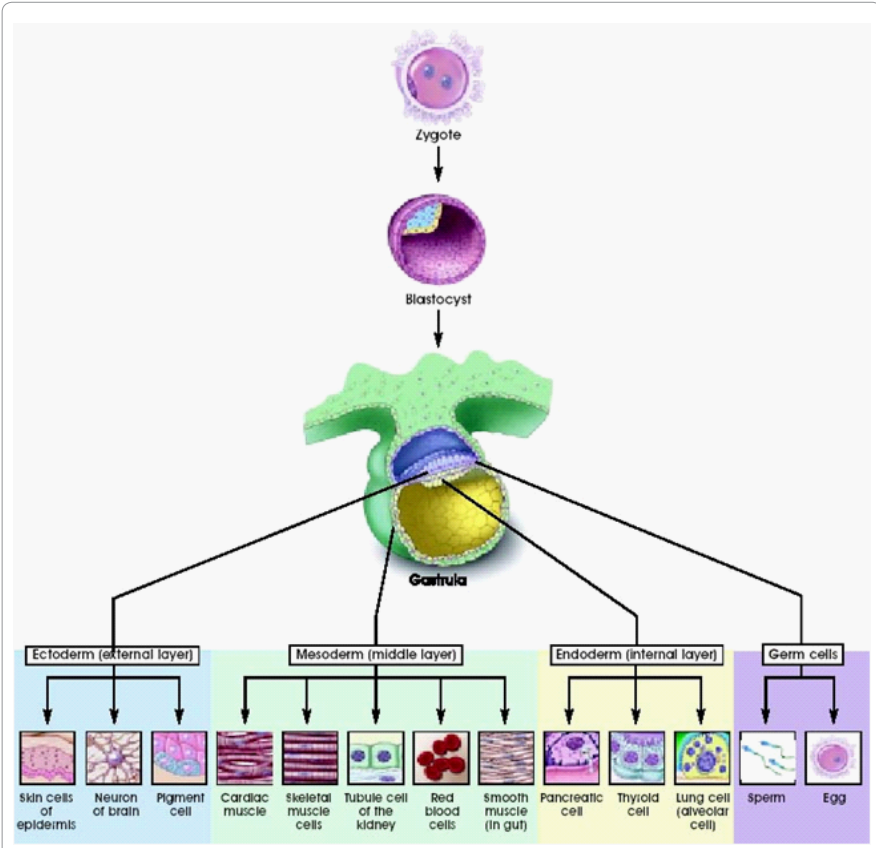

Figure 1: Derivation of all human tissues from germ layers. In particular, pancreatic cells take origin from the internal layer of endoderm. 
which allowed obtaining pancreatic cells from other cell types [73-75]. In all these cases it was achieved an adenoviral-mediated misexpression of Pdx1 in mouse liver observing a prevention of streptozotocininduced hyperglycemia in animal models. Besides this, Kaneto et al [76] showed that concomitant adenoviral application of two factors, Pdx1 and Ngn3 or NeuroD in the liver of mice caused a transdifferentiation of hepatic cells into insulin-producing cells associated to a significant amelioration of glucose-tolerance.

Intriguingly, also exocrine pancreatic cells have the capacity to generate their endocrine counterpart when exposed in vitro to a particular microenvironment consisting of agonists of the JAK2/ STAT3 signalling pathway as epidermal growth factor and leukemia inhibitory factor [77]. We report also our experience in a porcine model about the isolation, by a surgical microdissection, of Wirsung duct cells which, upon simple in vitro exposure to glucose, acquired the ability to secrete insulin and glucagon [28]. Finally it seems worthy of note the finding that human monocytes treated with macrophage colony-stimulating factor and interleukin 3 can transdifferentiate in pancreatic islet-like cells in a glucose dependent manner [78].

\section{Conclusions}

Regenerative medicine is one of the fields of research which has undergone the greatest development in the last few years. Undoubtedly diabetes cell therapy, for the enormous social and economical implications, is one of the most investigated branches of regenerative medicine.

The first therapeutic approaches, consisting of pancreas transplant and, more recently, islet transplantation, showed significant limits so alternative approaches based on a full knowledge of cellular and developmental biology of pancreatic cells have been under full consideration in the last years. Transdifferentiation, the process which lead an adult cell to change its phenotype into another, seems a promising approach given that adult cells are autologous and are not dangerous or potentially tumorigenic and free of ethical implications as, instead, embryonic stem cells.

In conclusion, despite promising experimental published data and regardless of the strategies to increase availability of $\beta$-cells, the transfer of the experimental results to the clinic still seems far away.

\section{Conflict of Interest Statement}

All authors declare the absence of any employment, consultancies, stock ownership, honoraria, paid expert testimony, patent applications/registrations, and grants which could inappropriately influence their work.

\section{References}

1. Gruessner AC (2011) 2011 update on pancreas transplantation: comprehensive trend analysis of 25,000 cases followed up over the course of twenty-four years at the International Pancreas Transplant Registry (IPTR). Rev Diabet Stud 8: $6-16$.

2. Ireland R (2011) Transplantation: Effect of pancreas-after-kidney transplant on renal graft survival. Nat Rev Nephrol 26: 486-492.

3. Federlin KF, Jahr H, Bretzel RG (2001) Islet transplantation as treatment of type 1 diabetes: from experimental beginnings to clinical application. Exp Clin Endocrinol Diabetes 109: S373-383

4. Street CN, Lakey JR, Shapiro AM, Imes S, Rajotte RV, et al. (2004) Islet graft assessment in the Edmonton Protocol: implications for predicting long-term clinical outcome. Diabetes 53: 3107-3114.

5. Ryan EA, Lakey JR, Rajotte RV, Korbutt GS, Kin T, et al. (2001) Clinical outcomes and insulin secretion after islet transplantation with the Edmonton protocol. Diabetes 50: 710-719

6. Arabi YM, Tamim HM, Rishu AH (2009) Hypoglycemia with intensive insulin therapy in critically ill patients: predisposing factors and association with mortality. Crit Care Med 37: 2536-2544.

7. Kaukonen KM, Rantala M, Pettilä V, Hynninen M (2009) Severe hypoglycemia during intensive insulin therapy. Acta Anaesthesiol Scand 53: 61-65.

8. Ryan EA, Paty BW, Senior PA, Bigam D, Alfadhli E, et al. (2005) Five-year follow-up after clinical islet transplantation. Diabetes 54: 2060-2069.

9. Froud T, Ricordi C, Baidal DA, Hafiz MM, Ponte G, et al. (2005) Islet transplantation in type 1 diabetes mellitus using cultured islets and steroid-free immunosuppression: Miami experience. Am J Transplant 5: 2037-2046.

10. Hirshberg B, Rother KI, Digon BJ, Lee J, Gaglia JL, et al. (2003) Benefits and risks of solitary islet transplantation for type 1 diabetes using steroid-sparing immunosuppression: the National Institutes of Health experience. Diabetes Care 26: 3288-3295.

11. Koh A, Imes S, Kin T, Dinyari P, Malcolm A, et al. (2010) Supplemental islet infusions restore insulin independence after graft dysfunction in islet transplant recipients. Transplantation 89: 361-365.

12. Faradji RN, Tharavanij T, Messinger S, Froud T, Pileggi A, et al. (2008) Long-term insulin independence and improvement in insulin secretion after supplemental islet infusion under exenatide and etanercept. Transplantation 86: $1658-1665$.

13. Pileggi A, Cobianchi L, Inverardi L, Ricordi C (2006) Overcoming the challenges now limiting islet transplantation: a sequential, integrated approach. Ann NY Acad Sci 1079: 383-398.

14. Vantyghem MC, Marcelli-Tourvieille S, Fermon C, Duhamel A, Raverdy V, et al (2009) Intraperitoneal insulin infusion versus islet transplantation: comparative study in patients with type 1 diabetes. Transplantation 87: 66-71.

15. Kessler L, Passemard R, Oberholzer J, Benhamou PY, Bucher P, et al. (2002) Reduction of blood glucose variability in type 1 diabetic patients treated by pancreatic islet transplantation: interest of continuous glucose monitoring Diabetes Care 25: 2256-2262.

16. Bassi R, Fiorina P (2011) Impact of islet transplantation on diabetes complications and quality of life. Curr Diab Rep 11: 355-363.

17. Vaithilingam V, Tuch BE (2011) Islet transplantation and encapsulation: an update on recent developments. Rev Diabet Stud 8: 51-67.

18. Ngoc PK, Phuc PV, Nhung TH, Thuy DT, Nguyet NT (2011) Improving the efficacy of type 1 diabetes therapy by transplantation of immunoisolated insulin-producing cells. Hum Cell 24: 86-95.

19. Johnson AS, O'Sullivan E, D'Aoust LN, Omer A, Bonner-Weir S, et al. (2011) Quantitative assessment of islets of Langerhans encapsulated in alginate. Tissue Eng Part C Methods 17: 435-449.

20. Hoesli CA, Raghuram K, Kiang RL, Mocinecová D, Hu X, et al. (2011) Pancreatic cell immobilization in alginate beads produced by emulsion and internal gelation. Biotechnol Bioeng 108: 424-434.

21. Mathew JM, Leventhal JR, Miller J (2011) Microchimerism in promoting graft acceptance in clinical transplantation. Curr Opin Organ Transplant 16: 345-352.

22. Gu G, Brown JR, Melton DA (2003) Direct lineage tracing reveals the ontogeny of pancreatic cell fates during mouse embryogenesis. Mech Dev 120: 35-43.

23. Noguchi $H$ (2007) Stem cells for the treatment of diabetes. Endocr J 54: 7-16.

24. Noguchi H, Kaneto H, Weir GC, Bonner-Weir S (2003) PDX-1 protein containing its own antennapedia-like protein transduction domain can transduce pancreatic duct and islet cells. Diabetes 52: 1732-1737.

25. Noguchi H, Matsumoto S, Ueda M, Hayashi S, Kobayashi N, et al. (2008) Method for isolation of mouse pancreatic stem cells. Transplant Proc 40: 422 433.

26. Bonner-Weir S, Taneja M, Weir GC, Tatarkiewicz K, Song KH, et al. (2000) In vitro cultivation of human islets from expanded ductal tissue. Proc Natl Acad Sci USA 97: 7999-8004. 
27. Gao R, Ustinov J, Pulkkinen MA, Lundin K, Korsgren O, et al. (2003) Characterization of endocrine progenitor cells and critical factors for their differentiation in human adult pancreatic cell culture. Diabetes 52: 2007-2015.

28. Gioviale MC, Damiano G, Montalto G, Buscemi G, Romano M, et al. (2009) Isolation and culture of beta-like cells from porcine Wirsung duct. Transplant Proc 41: 1363-1366.

29. Stassi G, Todaro M, Richiusa P, Giordano M, Mattina A, et al. (1995) Expression of apoptosis-inducing CD95 (Fas/Apo-1) on human beta-cells sorted by flowcytometry and cultured in vitro. Transplant Proc 27: 3271-3275.

30. Dor Y, Brown J, Martinez OI, Melton DA (2004) Adult pancreatic beta-cells are formed by self-duplication rather than stem-cell differentiation. Nature 429 : $41-46$.

31. Xu X, D'Hoker J, Stange G, Bonné S, De Leu N, et al. (2008) Beta cells can be generated from endogenous progenitors in injured adult mouse pancreas. Cell 132: 197-207.

32. Lumelsky N, Blondel O, Laeng P, Velasco I, Ravin R, et al. (2001) Differentiation of embryonic stem cells to insulin-secreting structures similar to pancreatic islets. Science 292: 1389-1394.

33. D'Amour KA, Bang AG, Eliazer S, Kelly OG, Agulnick AD, et al. (2006) Production of pancreatic hormone-expressing endocrine cells from human embryonic stem cells. Nat Biotechnol 11: 1392-1401.

34. Jiang J, Au M, Lu K, Eshpeter A, Korbutt G, et al. (2007) Generation of insulin producing islet-like clusters from human embryonic stem cells. Stem Cells 25: 1940-1953.

35. Tateishi K, He J, Taranova O, Liang G, D’Alessio AC et al. (2008) Generation of insulin-secreting islet-like clusters from human skin fibroblasts. J Biol Chem 283: 31601-31607

36. Maehr R, Chen S, Snitow M, Ludwig T, Yagasaki L, et al. (2009) Generation of pluripotent stem cells from patients with type 1 diabetes. Proc Natl Acad Sci USA 106: 15768-15773.

37. Xie QP, Huang H, Xu B, Dong X, Gao SL, et al. (2009) Human bone marrow mesenchymal stem cells differentiate into insulin-producing cells upon microenvironmental manipulation in vitro. Differentiation 77: 483-491.

38. Noguchi H, Naziruddin B, Shimoda M, Fujita Y, Chujo D, et al. (2010) Induction of insulin-producing cells from human pancreatic progenitor cells. Transplant Proc 42: 2081-2083.

39. Seaberg RM, Smukler SR, Kieffer TJ, Enikolopov G, Asghar Z, et al. (2004) Clonal identification of multipotent precursors from adult mouse pancreas that generate neural and pancreatic lineages. Nat Biotechnol 22: 1115-1124.

40. Yang L, Li S, Hatch H, Ahrens K, Cornelius JG, et al. (2002) In vitro transdifferentiation of adult hepatic stem cells into pancreatic endocrine hormone producing cells. Proc Natl Acad Sci U S A 99: 8078-8083.

41. Sun B, Roh KH, Lee SR, Lee YS, Kang KS, et al. (2007) Induction of human umbilical cord blood derived stem cells with embryonic stem cell phenotypes into insulin producing islet-like structure. Biochem Biophys Res Commun 354: 919-923.

42. Chao KC, Chao KF, Fu YS, Liu SH (2008) Islet-like clusters derived from mesenchymal stem cells in Wharton's Jelly of the human umbilical cord for transplantation to control type 1 diabetes. PLoS One 3: e1451-e1458.

43. Chang CM, Kao CL, Chang YL, Yang MJ, Chen YC, et al. (2007) Placenta derived multipotent stem cells induced to differentiate into insulin-positive cells. Biochem Biophys Res Commun 357: 414-420.

44. Lee AS, Tang C, Cao F, Xie X, van der Bogt K, et al. (2009) Effects of cell number on teratoma formation by human embryonic stem cells. Cell Cycle 8 : 2608-2612.

45. Boyd AS, Wu DC, Higashi Y, Wood KJ (2008) A Comparison of Protocols Used to Generate Insulin-Producing Cell Clusters from Mouse Embryonic Stem Cells. Stem Cells 26: 1128-1113.

46. Blyszczuk P, Asbrand C, Rozzo A, Kania G, St-Onge L, et al. (2004) Embryonic stem cells differentiate into insulin-producing cells without selection of nestinexpressing cells. Int J Dev Biol 48: 1095-1104.
47. Kitano M, Kakinuma M, Takatori A, Negishi T, Ishii Y, et al. (2006) Gene expression profiling of mouse embryonic stem cell progeny differentiated by Lumelsky's protocol. Cells Tissues Organs 183: 24-31.

48. Rajagopal J, Anderson WJ, Kume S, Martinez OI, Melton DA, et al. (2003) Insulin staining of ES cell progeny from insulin uptake. Science 299: 363-368.

49. Gradwohl G, Dierich A, Elmer M, Guillemot F (2000) neurogenin3 is required for the development of the four endocrine cell lineages of the pancreas. Proc Natl Acad Sci USA 97: 1607-1611.

50. Zuk PA, Zhu M, Ashjian P, De Ugarte DA, Huang JI, et al. (2002) Human adipose tissue is a source of multipotent stem cells. Mol Biol Cell 13: 42794295.

51. Timper K, Seboek D, Eberhardt M, Linscheid P, Christ-Crain M, et al. (2006) Human adipose tissue-derived mesenchymal stem cells differentiate into insulin, somatostatin, and glucagon expressing cells. Biochem Biophys Res Commun 341: 1135-1140.

52. Lee J, Han DJ, Kim SC (2008) In vitro differentiation of human adipose tissue derived stem cells into cells with pancreatic phenotype by regenerating pancreas extract. Biochem Biophys Res Commun 375: 547-551.

53. Chandra V, Swetha G, Muthyala S, Jaiswal AK, Bellare JR, et al. (2011) IsletLike Cell Aggregates Generated from Human Adipose Tissue Derived Stem Cells Ameliorate Experimental Diabetes in Mice. PLoS One 6: e20615-e20627.

54. Phadnis SM, Joglekar MV, Dalvi MP, Muthyala S, Nair PD, et al. (2011) Human bone marrow-derived mesenchymal cells differentiate and mature into endocrine pancreatic lineage in vivo. Cytotherapy 13: 279-293.

55. Kadam SS, Bhonde RR (2010) Islet neogenesis from the constitutively nestin expressing human umbilical cord matrix derived mesenchymal stem cells Islets 2: 112-120.

56. Lo Monte A, Maione C, Basile V, Napoli N, Stassi G, et al. (1996) Pancreatic harvesting from multiorgan donors for islet transplantation. Minerva Chir 51 759-764.

57. Gioviale MC, Damiano G, Palumbo VD, Bellavia M, Cacciabaudo F, et al. (2011) Pancreatic islets from non-heart-beating donor pig: two-layer preservation method in an in vitro porcine model. Int J Artif Organs 34: 519-525.

58. Gioviale MC, Damiano G, Cacciabaudo F, Palumbo VD, Bellavia M, et al (2011) A good breath of oxygen for beta-like cells obtained from porcine exocrine pancreatic tissue. Transplant Proc 43: 1173-1177.

59. Zanone MM, Favaro E, Camussi G (2008) From endothelial to beta cells: insights into pancreatic islet microendothelium. Curr Diabetes Rev 4: 1-9.

60. Johansson M, Mattsson G, Andersson A, Jansson L, Carlsson PO (2006) Islet endothelial cells and pancreatic beta-cell proliferation: studies in vitro and during pregnancy in adult rats. Endocrinology 147: 2315-2324.

61. Cabric S, Sanchez J, Johansson U, Larsson R, Nilsson B, et al. (2010) Anchoring of vascular endothelial growth factor to surface-immobilized heparin on pancreatic islets: implications for stimulating islet angiogenesis. Tissue Eng Part A 16: 961-970.

62. Asahara T, Murohara T, Sullivan A, Silver M, van der Zee R, et al. (1997) Isolation of putative progenitor endothelial cells for angiogenesis. Science 275 964-967.

63. Di Santo S, Yfang Z, Wyler von Ballmoos M, Voelzmann J, Diehm N, et al. (2009) Novel cell-free strategy for therapeutic angiogenesis: in vitro generated conditioned medium can replace progenitor cell transplantation. PLoS One 4 e5643-e5648.

64. Park KS, Kim YS, Kim JH, Choi B, Kim SH, et al. (2010) Trophic molecules derived from human mesenchymal stem cells enhance survival, function, and angiogenesis of isolated islets after transplantation. Transplantation 89: 509517 .

65. Mathews V, Hanson PT, Ford E, Fujita J, Polonsky KS, et al. (2004) Recruitment of bone marrow-derived endothelial cells to sites of pancreatic beta-cell injury Diabetes 53: 91-98.

66. Sakata N, Chan NK, Chrisler J, Obenaus A, Hathout E, et al. (2010) Bone marrow cell cotransplantation with islets improves their vascularization and function. Transplantation 89: 686-693. 
Citation: Gioviale MC, Bellavia M, Damiano G, Buscemi G (2011) Cell Therapy in Type 1 Diabetes. J Stem Cell Res Ther S2:004. doi:10.4172/21577633.S2-004

67. Ito T, Itakura S, Todorov I, Rawson J, Asari S, et al. (2010) Mesenchymal stem cell and islet co-transplantation promotes graft revascularization and function. Transplantation 89: 1438-1445.

68. Luo L, Badiavas E, Luo JZ, Maizel A (2007) Allogeneic bone marrow supports human islet beta cell survival and function over six months. Biochem Biophys Res Commun 361: 859-864.

69. Hasegawa Y, Ogihara T, Yamada T, Ishigaki Y, Imai J, et al. (2007) Bone marrow (BM) transplantation promotes beta-cell regeneration after acute injury through BM cell mobilization. Endocrinology 148: 2006-2015.

70. Li FX, Zhu JW, Tessem JS, Beilke J, Varella-Garcia M, et al. (2003) The development of diabetes in E2f1/E2f2 mutant mice reveals important roles for bone marrow-derived cells in preventing islet cell loss. Proc Natl Acad Sci USA 100: $12935-12940$

71. Kordowich S, Mansouri A, Collombat $P$ (2010) Reprogramming into pancreatic endocrine cells based on developmental cues. Mol Cell Endocrinol 315: 11-18.

72. Gu G, Brown JR, Melton Da (2003) Direct lineage tracing reveals the ontogeny of pancreatic cell fates during mouse embryogenesis. Mech Dev 120: 35-43.

73. Ber I, Shternhall K, Perl S, Ohanuna Z, Goldberg I, et al. (2003) Functional, persistent, and extended liver to pancreas transdifferentiation. J Biol Chem 278: 31950-31957

74. Taniguchi H, Yamato E, Tashiro F, Ikegami H, Ogihara T, et al. (2003) Betacell neogenesis induced by adenovirus-mediated gene delivery of transcription factor Pdx1 into mouse pancreas. Gene Ther 10: 15-23.

75. Shternhall-Ron K, Quintana Fj, Perl S, Meivar-Levy I, Barshack I, et al. (2007) Ectopic PDX1 expression in liver ameliorates type 1 diabetes. J Autoimmun 28: 134-142.

76. Kaneto H, Nakatani Y, Miyatsuka T, Matsuoka TA, Matsuhisa M, et al. (2005) PDX1/VP16 fusion protein, together with NeuroD or Ngn3, markedly induces insulin gene transcription and ameliorates glucose tolerance. Diabetes 54 1009-1022.

77. Baeyens $L$, Bouwens $L$ (2008) Can $\beta$-cells be derived from exocrine pancreas? Diabetes, Obesity and Metabolism, 10: 170-178.

78. Ruhnke M, Ungefroren H, Nussler A, Martin F, Brulport M, et al. (2005) Differentiation of In Vitro-Modified Human Peripheral Blood Monocytes Into Hepatocyte-like and Pancreatic Islet-like Cells. Gastroenterology 128: 1774 1786 . 